\title{
Sylwia Adamczak-Krysztofowicz
}

Uniwersytet im. Adama Mickiewicza, Poznań https://orcid.org/0000-0002-7726-3525 adamczak@amu.edu.pl

Krystyna Mihułka

Uniwersytet Rzeszowski https://orcid.org/0000-0002-8665-4296 kmihulka@gmail.com

\section{KSZTAŁCENIE INTERKULTUROWE W DYDAKTYCE JĘZYKA NIEMIECKIEGO W POLSCE I W BADANIACH GERMANISTÓW. ANALIZA PORÓWNAWCZA WYBRANYCH DOKUMENTÓW I MATERIAŁÓW GLOTTODYDAKTYCZNYCH}

\author{
Intercultural education in German language teaching in Poland \\ and in German studies. Comparative analysis of selected documents \\ and glottodidactic materials
}

This article is intended to contribute to the academic debate on intercultural German language teaching and the relevant research in Poland. The authors present a critical overview and analysis of selected constituent aspects of intercultural education and keywords which are important for the evaluation of goals and content within the framework of interculturally-oriented teaching of German in Poland. The authors also discuss the form of presentation of intercultural aspects of education in The Common European Framework of Reference for Languages: Learning, teaching, assessment (Council of Europe, 2001), in the Polish core curriculum and in selected German language teaching materials which are meant to shape the intercultural competence of Polish learners at different levels of proficiency and in different types of schools. 
Keywords: intercultural education, intercultural competence, teaching German as a foreign language in Poland, comparative analysis, teaching materials, Common European Framework of Reference for Languages: Learning, teaching, assessment, core curriculum for modern foreign language

Słowa kluczowe: kształcenie interkulturowe, kompetencja interkulturowa, dydaktyka języka niemieckiego w Polsce, analiza porównawcza, materiały glottodydaktyczne, Europejski System Opisu Kształcenia Językowego: uczenie się, nauczanie, ocenianie, Podstawa Programowa dla języka obcego nowożytnego

\section{Uwagi wstępne}

Kształcenie interkulturowe stanowi już od ostatniej dekady XX wieku nieodłączny przedmiot rozważań teoretycznych, jak również praktycznie zorientowanych projektów i modeli w procesie przyswajania języka obcego w warunkach obcokulturowych. W związku z ogromnym zainteresowaniem problematyką interkulturową naukowcy zagraniczni (m.in. Maletzke, 1996; Byram, 1997; Altmayer, 2004; Bolten, 2007; Auernheimer, 2010; Hansen, 2011) i polscy (np. Karolak, 1999; Zawadzka, 2000, 2004; Pfeiffer; 2001, 2004 ${ }^{1}$; Adamczak-Krysztofowicz, 2003; Aleksandrowicz-Pędich, 2005; Myczko, 2005; Bandura, 2007; Jaroszewska, 2007; Torenc, 2007; Błażek, 2008; Białek, 2009; Mihułka, 2010, 2012; Karpińska-Musiał, 2015) prowadzili w ostatnich trzech dziesięcioleciach teoretyczne rozważania i badania dotyczące ewaluacji celów, treści, technik i środków glottodydaktycznych, efektywnych nie tylko dla osiągania rezultatów na poziomie kompetencji lingwistycznej, ale również wspierających proces sukcesywnego rozwijania wśród uczniów interkulturowej kompetencji komunikacyjnej. Ze względu na ograniczone miejsce nie jest możliwe zreferowanie w ramach jednego artykułu wszystkich ważnych badań polskich germanistów, którzy zajęli się możliwościami rozwoju i ewaluacji kompetencji interkulturowej w dydaktyce języka niemieckiego w Polsce. W związku z tym, przedstawiając podejście interkulturowe w nauczaniu języka niemieckiego $\mathrm{w}$ naszym kraju, skupimy się w niniejszym opracowaniu przede wszystkim na krytycznej ewaluacji dokumentów określających edukację językową, programów oraz materiałów glottodydaktycznych, badając w nich stopień realizacji głównych

\footnotetext{
1 Pfeiffer (2004: 81) ukuł pojęcie o nazwie glottopedagogika interkulturowa, poszerzając profil badawczy glottodydaktyki o większą rolę pedagogiki w celu nie tylko opanowania języka jako środka komunikacji, ale również kształcenia pozytywnej postawy wobec inności na podstawie wiedzy o kulturze, zwyczajach i mentalności innej społeczności komunikacyjnej.
} 
założeń nauczania interkulturowego w warunkach zinstytucjonalizowanych. Prezentację najważniejszych wniosków z analiz dokumentów i podręczników kursowych przeznaczonych dla poszczególnych etapów edukacyjnych poprzedza rys historyczny, w którym przedstawiono rozwój interkulturowości ze szczególnym uwzględnieniem polskiej rzeczywistości oraz zdefiniowano pojęcia kluczowe.

\section{Interkulturowość - rys historyczny z uwzględnieniem pojęć kluczowych}

Do rozwoju współczesnego podejścia interkulturowego w nauczaniu języka niemieckiego, doprowadziły zmiany koncepcji treści krajo- i kulturoznawstwa obcojęzycznego uwzględnianych w nauczaniu wszystkich języków obcych w ostatnich dwóch stuleciach. I tak przykładowo na początku elementy kulturoznawcze znalazły szczególne uznanie w preferowanych przez metodę gramatyczno-tłumaczeniową tekstach literackich, które traktowano jako świadectwo osiągnięć umysłowych danej wspólnoty językowej. Po reformie lat osiemdziesiątych XIX wieku treści bliskie komunikacji codziennej wyeksponowano w dialogach metody bezpośredniej dotyczących życia codziennego podręcznikowej rodziny, które całkowicie podporządkowane zostały nauczaniu języka.

Jednakże dopiero komunikacyjny przewrót lat siedemdziesiątych i osiemdziesiątych ostatniego stulecia, spowodował prawdziwie żywą dyskusję nad miejscem wiedzy z zakresu socjoznawstwa ${ }^{2}$ w dydaktyce języków obcych i doprowadził do stopniowego przesunięcia punktu ciężkości kognitywnej koncepcji krajoznawczej wiedzy encyklopedycznej w kierunku rozwijania umiejętności komunikacyjnych w kontaktach z przedstawicielami obcej kultury.

Całkowita rezygnacja z wiedzy faktograficznej, tła historycznego oraz redukcja tematyki krajo- i kulturoznawczej do treści dnia codziennego obcej wspólnoty kulturowej stały się jednak po pewnym czasie przedmiotem krytyki, której reperkusją było zaproponowanie podejścia interkulturowego w dydaktyce języków obcych, koncentrującego się na analizie porównawczej kulturowo uwarunkowanych różnic w zachowaniach językowych, pozajęzykowych, ale również para- i ekstrawerbalnych oraz ich wpływie na komunikację z przedstawicielami obcej kultury (zob. Adamczak-Krysztofowicz, 2007: 41). O miejscu

\footnotetext{
${ }^{2}$ W swojej koncepcji kulturoznawstwa w szerszym rozumieniu Pfeiffer (2001: 157159), wyróżnia cztery podstawowe płaszczyzny informacji istotne dla obcokulturowej socjalizacji: realioznawstwo (tzn. wiedzę o obcej rzeczywistości materialnej), krajoznawstwo (czyli wiadomości z dziedziny historii, geografii, gospodarki etc. danego kraju), socjoznawstwo (to jest znajomość zwyczajów oraz form zachowania się i wyrażania rodzimych użytkowników języka) i kulturoznawstwo sensu stricto zajmujące się takimi produktami umysłu ludzkiego jak muzyka, literatura, malarstwo, architektura.
} 
i roli tego przypisującego duże znaczenie ocenie obcych zjawisk kulturowych, ich relatywizacji i pozbawionego uprzedzeń porównania z kulturą rodzimą podejścia w dydaktyce języka niemieckiego dyskutuje się w Polsce od końca lat 80tych XX wieku. Tej tematyce poświęcono przykładowo w 1987 roku sympozjum w Zaborowie, którego głównym celem było analityczne szukanie „możliwie jak najdokładniejszego oświetlenia z jednej strony pojęcia języka, kompetencji językowej, kompetencji komunikatywnej, a z drugiej pojęcia kultury, kompetencji kulturowej" (Grucza, 1992a: 6). Treści pozajęzykowe pozwalające kształtować interkulturową kompetencję komunikacyjną na poziomie zaawansowanym u przyszłych nauczycieli i tłumaczy języka niemieckiego omawiano również w 2009 roku na konferencji w Obrzycku, starając się jasno sprecyzować terminy kluczowe interkulturowości oraz rozważając możliwości i ograniczenia kształcenia interkulturowego uprawianego w warunkach akademickich (zob. Adamczak-Krysztofowicz, Kowalonek-Janczarek, Maciejewski i Sopata, 2011: 7-11). Na aspekt interkulturowy w teorii i praktyce translatorycznej i glottodydaktycznej zwrócono także uwagę w aktualnej monografii wieloautorskiej „Interkulturalität in Theorie und Praxis der Glottodidaktik und Translatorik" (zob. Mihułka, Bąk i Chojnacka-Gärtner, 2016: 7-8).

Analiza wymienionego przykładowo powyżej niemieckojęzycznego piśmiennictwa glottodydaktycznego pozwala konstatować, że kluczowym zadaniem mającego wymiar kognitywny, afektywny i działaniowy nauczania interkulturowego jest wykształcenie u uczących się tzw. interkulturowej kompetencji komunikacyjnej obejmującej m.in. następujące kognitywne, afektywne i działaniowe elementy:

- kompetencję komunikacyjną czyli interakcyjną umiejętność płynnego i adekwatnego do sytuacji użycia języka. Budulcem tej kompetencji są: kompetencja formalno-językowa (lingwistyczna), kompetencja dyskursywna, kompetencja socjolingwistyczna, kompetencja socjokulturowa oraz kompetencja strategiczna (zob. strukturę pojęcia kompetencji komunikatywnej oraz podsumowanie dyskusji na ten temat u Gruczy (1992b: 28-30)),

- kompetencję (inter)kulturową tzn. „kompleks analityczno-strategicznych umiejętności w stosunkach z przedstawicielami innych narodowości" (Zawadzka, 2000: 453). Kompetencja ta obejmuje zdaniem Gruczy (1992b: 50) obok zdolności posługiwania się kulturą jako określonym systemem reguł generatywnych również „umiejętność interakcyjnego posługiwania się tworami kulturowymi, ich celowego tworzenia i nadania, ich interpretowania itd.",

- umiejętność „rozumienia obcości” (Fremdverstehen) czyli „uświadomienie sobie znaczenia kontrastu kulturowego drogą m.in. relatywizacji doświadczeń poznawczych" (Karolak, 1999: 10). Proces ten ma charakter 
dwustronny i uwzględnia nie tylko wiedzę na temat obcej wspólnoty kulturowej, ale także elementy wiedzy i doświadczeń z kultury rodzimej,

- zdolność empatii czyli umiejętność abstrahowania od własnego punktu widzenia i przejmowania obcych stanów emocjonalnych,

- gotowość do relatywizującego rozpatrywania własnej tożsamości, do zrozumienia motywów i sposobów działania innych oraz do przejmowania perspektywy postrzegania zjawisk obcokulturowych,

- kompetencję partycypacyjną tzn. orientację w zakresie procesów i relacji życia społecznego, politycznego, gospodarczego, kulturalnego oraz systemu administracji zarówno w obszarze kultury obcej jak i rodzimej,

- umiejętność rozpoznania problematycznych obszarów komunikacji międzyludzkiej (stereotypowych opinii, negatywnych uogólnień o przedstawicielach rodzimej i obcej wspólnoty kulturowej oraz konfliktogennych tematów i zachowań prowadzących do tzw. szoku kulturowego),

- umiejętność kulturowej samorefleksji,

- fleksybilność,

- tolerancję,

- otwartość kulturową oraz inne afektywne zdolności (zob. dokładniej Adamczak-Krysztofowicz, 2003: 40-42 oraz Mihułka, 2012:41-63).

Nie wdając się $w$ dalsze teoretyczne rozważania na temat modeli kompetencji i komunikacji interkulturowej ${ }^{3}$, warto zaprezentować wyniki analizy komponentu interkulturowego w polskiej polityce i edukacji językowej, ze szczególnym uwzględnieniem dydaktyki języka niemieckiego jako obcego.

\section{Specyfika kształcenia interkulturowego $w$ warunkach zinstytucjonalizowanych w Polsce na przykładzie dydaktyki języka niemieckiego jako obcego}

Podejście interkulturowe w Polsce osiągnęło już pełnoletność, zasadnym jest zatem dokonanie ewaluacji efektów osiągniętych w tym okresie. Oceniając stopień realizacji założeń kształcenia interkulturowego na lekcji języka niemieckiego

\footnotetext{
3 Przegląd tych modeli z uwzględnieniem kluczowych pojęć interkulturowości opracowały m.in. Błażek (2008: 27-67), Mihułka (2012: 21-74), Adamczak-Krysztofowicz, Jentges i Stork (2015: 12-21). Wszystkie wspomniane modele nawiązują do trójpodziału kompetencji interkulturowej, w którym wyróżnia się płaszczyznę wiedzy, postaw i umiejętności. Autorzy badań zaprezentowanych w rozdziale 3 odnoszą się w sposób bezpośredni lub pośredni (już w wachlarzach kryteriów, na podstawie których przebiegało badanie, lub we wnioskach wyprowadzonych na jego bazie) do komponentu kognitywnego, afektywnego i zorientowanego na działanie tejże kompetencji. Podział ten stanowi również podstawę naszych rozważań ujętych w rozdziale 3 i 4 niniejszego artykułu.
} 
jako obcego w Polsce, warto skupić się na wybranych elementach układu glottodydaktycznego Pfeiffera (2001: 21). Na początku należałoby przybliżyć rezultaty analiz dokumentów regulujących kształcenie językowe w Polsce oraz niektórych programów i kursów do nauki języka niemieckiego jako obcego pod kątem uwzględnienia w nich aspektu interkulturowego.

\subsection{Interkulturowość w polskiej polityce językowej}

Kształcenie językowe w Polsce regulują od momentu przyjęcia Polski do Unii Europejskiej dwa zasadnicze dokumenty Europejski System Opisu Kształcenia Językowego: uczenie się, nauczanie, ocenianie (dalej ESOKJ) i Podstawa Programowa (dalej $P P$ ), w których opisano kompetencje, sprawności i umiejętności, jakie powinny posiąść osoby uczące się języka obcego na kolejnych poziomach biegłości językowej.

Na podstawie wnikliwej analizy ESOKJ pod kątem odniesień do realizacji założeń edukacji interkulturowej stwierdzono, że aspekt interkulturowy poruszony został we wstępie dokumentu oraz w rozdziale poświęconym kompetencjom, a zupełnie pominięty w opisie poziomów biegłości językowej oraz w rozdziale o ocenianiu. W całym dokumencie brak jakichkolwiek wskazówek dotyczących możliwości oceniania postępów w nabywaniu kompetencji interkulturowej jako całości lub jej poszczególnych płaszczyzn. Ponadto nie wszystkie kluczowe dla kształcenia interkulturowego terminy zostały w ogóle lub w jednoznaczny sposób zdefiniowane, $\mathrm{np}$. kompetencja interkulturowa, osobowość interkulturowa, wrażliwość interkulturowa, pośrednik kulturowy. Jest to prawdopodobnie po części wynikiem otwartej formy dokumentu, szczególnie fragmentów, w których autorzy opracowania proponują jego użytkownikom „rozważenie, a jeśli uznają za stosowne” określenie danych kwestii na podstawie pomocniczych punktów w formie pytań lub stwierdzeń. Niestety należy mieć spore wątpliwości co do tego, czy te pytania, bardzo istotne w kontekście rozwijania kompetencji interkulturowej u uczniów, doczekają się odpowiedzi (por. Bandura, 2007: 112-120; Mihułka, 2012: 107-110).

Odniesienia do edukacji interkulturowej znalazły się w $P P^{4}$ w postanowieniach ogólnych (zadaniach szkoły, wstępie) dotyczących kształcenia ogólnego, co

\footnotetext{
${ }^{4}$ W związku z tym, że większość zaprezentowanych w niniejszym artykule analiz programów nauczania i podręczników do nauki języka niemieckiego pochodzi z okresu obowiązywania wcześniejszych PP, właśnie na tych dokumentach skoncentrowano się w rozdziale poświęconym interkulturowości w polskiej polityce językowej, a celowo zrezygnowano ze szczegółowego opisu aktualnie obowiązującej PP. Dodać należy, że podział na etapy edukacyjne stosowany w niniejszym artykule odpowiada zapisom zawartym we wcześniejszych wersjach $P P$.
} 
oznacza, że proces kształtowania osobowości (interkulturowej) uczniów powinien być wspierany przez nauczycieli wszystkich przedmiotów, którzy ponadto powinni dołożyć wszelkich starań, aby solidnie przygotować uczniów do funkcjonowania w wielokulturowym świecie. Fakt, że aspekt interkulturowy pojawił się tylko we wstępie dokumentu i nie stał się przedmiotem analiz w części poświęconej kształceniu językowemu, może prowadzić wśród nauczycieli języków obcych do błędnego przekonania, że rozwijanie kompetencji interkulturowej u uczniów nie jest jednym z kluczowych celów lekcji języka obcego. W PP z 2010 roku zasygnalizowano wprawdzie ważność komponentu kognitywnego kompetencji interkulturowej w kształceniu językowym, jednak zalecenia tego nie opatrzono żadnym komentarzem (por. Mihułka, 2012: 110-115; Chojnacka-Gärtner, 2016: 65-66). ${ }^{5}$

Reasumując, przydatność ESOKJ i PP dla nauczycieli języków obcych, autorów podręczników i programów nauczania, którzy chcieliby zdobyć informacje dotyczące rozwijania kompetencji interkulturowej u uczniów i jej ewaluacji, jest ograniczona, a luki i uchybienia, dotyczące wdrażania w praktykę szkolną celów kształcenia interkulturowego, rzutują w sposób bezpośredni na jakość programów nauczania języka niemieckiego, co potwierdzają poniżej zaprezentowane wnioski $z$ analiz.

Programy wczesnoszkolnego nauczania języków obcych odznaczają się zdaniem Jaroszewskiej (2006: 297-298; 2007: 188-198) z jednej strony solidnie sformułowanymi celami szczegółowymi, wychodzącymi poza wytyczne $P P \mathrm{w}$ kwestii kształtowania w dzieciach postawy otwartości względem innych kultur i świadomości wielokulturowej, z drugiej zaś strony „proponowane [w tych programach] treści czy zakresy tematyczne nie uwzględniają już w tak znaczącym stopniu problematyki wielokulturowości, przy czym ograniczają się najczęściej jedynie do opisu postaci, świąt, podróży, najbliższego środowiska dziecka (dom, szkoła itp.)" (Jaroszewska, 2006: 298; 2007: 195). Ponadto, jak zauważa badaczka, brak w nich jakichkolwiek wskazówek dla nauczyciela dotyczących włączenia w proponowany tok zajęć treści interkulturowych. Do podobnych wniosków dochodzi na podstawie analiz wybranych programów nauczania

\footnotetext{
${ }^{5}$ W PP z 2017 roku dla I i ll etapu edukacyjnego odniesienia do kształcenia interkulturowego zamieszczone zostały w postanowieniach ogólnych (kształtowanie w uczniach postawy otwartej wobec świata i innych ludzi) oraz w treściach szczegółowych. Na I etapie edukacyjnym skoncentrowano się przede wszystkim na komponencie kognitywnym, na II zamieszczono odniesienia do wszystkich trzech komponentów kompetencji interkulturowej. Hasłowe zalecenia nie zostały jednak rozwinięte przez autorów dokumentu (por. Podstawa programowa kształcenia ogólnego z komentarzem. Szkoła podstawowa. Język obcy nowożytny. https://cke.gov.pl/images/_EGZAMIN_OSMOKL ASISTY/Podstawa_programowa/SP_PP_2017_Jezyk_obcy_nowozytny.pdf).
} 
języka niemieckiego dla IV etapu edukacyjnego Mihułka (2012: 120-127), zaznaczając, że za wyjątkiem celów szczegółowych i (ogólno)wychowawczych, zaczerpniętych zresztą bezpośrednio z $P P$ i akcentujących konieczność rozwijania w uczniach postawy otwartości, tolerancji, ciekawości wobec innych kultur, jak i własnej tożsamości kulturowej, programy nie oferują żadnych bezpośrednich odniesień do wagi założeń edukacji interkulturowej w procesie przyswajania języka obcego. Autorzy programów nie zamieścili także żadnych instrukcji dla nauczycieli, którzy jednak byliby zainteresowani włączeniem problematyki interkulturowej w swoje lekcje.

Mając na uwadze wyżej wymienione braki programów nauczania, szczególnie w obrębie treści programowych, które nie korespondują z nakreślonymi celami, można wnioskować, że ich autorzy kluczowe miejsce w procesie kształtowania kompetencji interkulturowej u uczniów przypisują materiałom glottodydaktycznym (powstałym przecież na bazie tych programów!) oraz nauczycielom języka niemieckiego. $W$ tym miejscu warto wspomnieć, że bez jasnego określenia w programach nauczania języków obcych celów, treści i procedur koniecznych do promowania edukacji interkulturowej wprowadzanie komponentu interkulturowego na lekcjach języka obcego będzie nosiło znamiona przypadkowości, nie będzie zatem skutkiem świadomych i dokładnie zaplanowanych działań nauczyciela.

\subsection{Materiały glottodydaktyczne a realizacja założeń kształcenia interkulturowego}

Pomimo coraz większej dominacji nowoczesnych mediów podręcznik wraz z materiałami okołopodręcznikowymi pozostaje nadal nieodłącznym elementem procesu nauczania i uczenia się języka obcego (niemieckiego) w warunkach zinstytucjonalizowanych. Opracowaniom tym, stanowiącym materialną bazę procesów glottodydaktycznych, przypisuje niezwykle ważną rolę Pfeiffer (2001: 161), ponieważ z jednej strony bez nich w zasadzie trudno wyobrazić sobie naukę języka obcego, z drugiej zaś jest w nich zawarty „,język glottodydaktyki". Bezsprzecznym pozostaje również fakt, że zakres wiedzy o kraju / krajach nauczanego języka oraz sposób jej przekazywania na lekcjach uzależniony jest w dużej mierze właśnie od podręcznika.

Zaprezentowane poniżej analizy materiałów do nauki języka niemieckiego dla $\mathrm{I} / \mathrm{I}^{6}$, III, IV etapu edukacyjnego pod kątem wspierania rozwoju kompetencji interkulturowej u odbiorców pochodzą z ostatnich dwóch dekad i przeprowadzone

\footnotetext{
${ }^{6}$ W związku z tym, że w polskich szkołach język niemiecki jest drugim językiem obcym, jego nauka rozpoczyna się w najlepszym wypadku od IV klasy szkoły podstawowej. Niektóre z omówionych podręczników używane są zatem również na II etapie edukacyjnym.
} 
zostały na podstawie oryginalnych wachlarzy kryteriów. ${ }^{7}$ Ich autorzy niejednokrotnie zwracali uwagę na różnice pomiędzy podręcznikami lokalnymi i globalnymi, szczególnie w kwestiach dotyczących realizowanych celów. Najogólniej rzecz ujmując, te pierwsze nastawione są głównie na cele stricte językowe, te drugie zaś zorientowane są na przekazywanie treści kulturowych i realizowanie celów komunikacyjnych, a to oznacza, że żadne z nich nie wspomagają nauczania interkulturowego w zadowalającym stopniu. Powyższą konstatację potwierdza Jańska (2006: 165-299), która na podstawie analiz materiałów przeznaczonych dla I/II etapu edukacyjnego ${ }^{8}$ zauważa, że podstawowym celem podręczników lokalnych jest rozwój wąsko rozumianej kompetencji językowej, co jest przynajmniej częściowo podyktowane małą liczbą godzin (1-2 tygodniowo), przeznaczoną w polskich szkołach na drugi język obcy (niemiecki). Autorka dodaje, że podręczniki globalne, nastawione na zintegrowane nauczanie języka i kultury, zawierają znacznie więcej treści kulturoznawczych dotyczących niemieckiego obszaru językowego w porównaniu z globalnymi. Problem jednak $w$ tym, że $z$ racji swojego uniwersalnego charakteru, brak w nich bezpośrednich odniesień do kultury rodzimej odbiorców (kultury polskiej), w tym zadań konfrontatywnych pozwalających na dokonywanie porównań kultury obcej z własną, co „utrudnia [...] w znacznym stopniu realizację zamierzeń kształcenia interkulturowego” (Jańska, 2006: 302).

Podręczniki do nauki języka niemieckiego przewidziane dla gimnazjalistów ${ }^{9}$ również nie spełniają oczekiwań w kwestii wdrażania założeń kształcenia interkulturowego. Jarząbek (2016: 194-201; 2017: 56-67) zaznacza, że zadania, w których specyfika kulturowa jest celem samym w sobie, należą w analizowanych materiałach do rzadkości. Kolejność występowania tych zadań nie jest podyktowana

\footnotetext{
${ }^{7}$ We wspomnianych analizach kompetencję interkulturową postrzegano holistycznie lub odnoszono się do jej wszystkich lub wybranych komponentów w sposób pośredni lub bezpośredni. Fundament przywołanych analiz podręczników tworzyły szczegółowe wachlarze kryteriów (Jańska, 2006: 153-161; Mihułka, 2012: 119-120; Fus, 2015: 135-137) lub dość ogólne wytyczne (Mackiewicz, 2008: 204-207; Jarząbek, 2016:193194; 2017: 56) opracowane i scharakteryzowane przez ich autorów.

${ }^{8}$ Jańska (2006) uwzględniła w swojej analizie następujące serie do nauki języka niemieckiego dla I/II etapu edukacyjnego: Eins, zwei, drei. Podręcznik do języka niemieckiego; ich und du. Podręcznik do języka niemieckiego; KängooKängoo Deutsch; Kaspertheater rund ums Jahr; Tamburin. Podręcznik dla klasy I-III. Informacje ogólne dotyczące analizowanych kursów znajdują się w Jańska (2006: 166-167, 180, 194, 211, 226).

${ }^{9}$ Analizie poddano następujące kursy dla III etapu edukacyjnego: Aktion Deutsch; Das ist Deutsch Kompakt; Meine Deutschtour; Beste Freunde; www.wieter deutsch; Mit links; Magnet; Magnet smart; Kompass neu, Kompass. Dane bibliograficzne kursów objętych badaniem znaleźć można w Jarząbek (2016: 202).
} 
progresją językową, a te oferowane różnią się pod względem jakości i różnorodności. Autorka wskazała na fakt, że niektóre zadania sprzyjałyby rozwijaniu kompetencji interkulturowej u uczniów, gdyby polecenia do nich były inaczej sformułowane. W obecnej formie nie zawierają one żadnych bezpośrednich wzmianek skłaniających do refleksji interkulturowej, a to skutkuje właśnie pomijaniem celów interkulturowych w trakcie rozwiązywania tych zadań.

Analizy podręczników przeznaczonych dla IV etapu edukacyjnego ${ }^{10}$ (poziom A1-B1) również nie napawają optymizmem, w szczególności w odniesieniu do kursów cieszących się dużą popularnością wśród polskich nauczycieli szkół średnich, na co zwracali uwagę Mackiewicz (2008: 207-212; 2010: 144-148) i Mihułka (2012: 115-156; 2014a: 189-192). Analizowane cykle, z wyjątkiem jednego, nie sprzyjają zwiększeniu refleksji i wrażliwości interkulturowej u uczniów i nauczycieli. Koncentrują się one na rozwoju tylko jednego aspektu kompetencji interkulturowej, tj. komponentu kognitywnego. Omawiane podręczniki oferują najwięcej treści z zakresu realio- i krajoznawstwa ${ }^{11}$, chociaż w niektórych materiałach (Alles klar, Direkt) i ta problematyka została sprowadzona do podstawowych informacji (por. Mihułka 2012: 131-140; 151-152; 157). Pozostałe płaszczyzny kompetencji interkulturowej (afektywna i działaniowa) potraktowane zostały w opisywanych podręcznikach marginalnie, o czym już świadczy liczba oferowanych zadań oraz ich jakość (patrz np. Mihułka, 2012: 145-150; 152; 157). Elementy konfrontatywne, pozwalające na dokonywanie porównań kultury obcej z własną, uświadamianie sobie swojej własnej przynależności kulturowej oraz refleksyjne poznawanie obcej, występują we wspomnianych kursach w ilościach znikomych. Wyjątek stanowi seria Stufen International w pełni podporządkowana wymogom dydaktyki interkulturowej, która zdaniem Mackiewicza (2008: 209, 212) zbliża się do ideału podręcznika zorientowanego na promowanie założeń kształcenia interkulturowego.

$\mathrm{Na}$ interkulturowo zorientowanej dydaktyce języków obcych oparte są także inne globalne kursy do nauki języka niemieckiego, jak np. em neu i Aspekte ${ }^{12}$, przeznaczone jednak dla uczniów bardziej zaawansowanych językowo. Korzystają z nich zarówno studenci studiów germanistycznych, jak i polscy maturzyści, przygotowujący się do matury rozszerzonej z języka niemieckiego. Fus

${ }^{10}$ Stufen International, Passwort Deutsch, Alles klar, Berliner Platz, Alles klar - zakres podstawowy, Direkt. Podręczniki te mogą być używane również w nauczaniu dorosłych. Ogólną charakterystykę kursów Alles klar - zakres podstawowy, Direkt zamieściła Mihułka (2012: 118). Odnośniki bibliograficzne dotyczącze pozostałych analizowanych kursów z tej grupy znajdują się w Mackiewicz (2008: 212-213; 2010: 148-149).

${ }^{11}$ Patrz przypis nr 2.

12 Ogólne informacje dotyczące analizowanych serii znajdują się w Fus (2015: 133). 
(2015: 129-232) poddała te podręczniki analizie, uwzględniając następujące zagadnienia: język a kultura, kompetencja interkulturowa, wspieranie rozumienia obcości. W kontekście kształcenia interkulturowego godny odnotowania jest fakt, że teksty oferowane $w$ obu analizowanych seriach, stanowiące podstawę dla konfrontacji z obcą kulturą, cechuje autentyczność. Obydwa kursy uznane zostały za opracowania sprzyjające rozwijaniu kompetencji interkulturowej u osób z nich korzystających, jednakże w różnym natężeniu. Wyniki analizy pokazały bowiem, że w kursie Aspekte położony jest większy nacisk na realizację celów interkulturowych niż w em neu.

Na podstawie wyżej przytoczonych konkluzji nasuwają się pewne wnioski zbiorcze dotyczące tego, na ile podręczniki do nauki języka niemieckiego, często używane przez polskich nauczycieli, propagują realizację celów interkulturowych. Niestety właściwie we wszystkich materiałach ${ }^{13}$ poddanych analizie komponent interkulturowy jest słabo zarysowany, a stwierdzenie to dotyczy zarówno tekstów podręcznikowych, jak i oferowanych zadań. W tym miejscu należy dodać, że wbrew oczekiwaniom podręczniki lokalne wypadają w tym względzie gorzej niż globalne. Zakłada się bowiem, że ich autorzy będą mieć na uwadze zarówno specyfikę polskiego kontekstu edukacyjnego, jak i problematyczne aspekty natury językowej i kulturowej, będące następstwem różnic pomiędzy językiem polskim a niemieckim (i jego odmianami) oraz pomiędzy kulturą polską a kulturą poszczególnych krajów niemieckiego obszaru językowego. W wielu analizowanych kursach uwagę przykuwa również zredukowanie niemieckiego obszaru językowego tylko do Niemiec. Jeśli już pojawiają się informacje na temat innych krajów tego obszaru, głównie Austrii i Szwajcarii, to są one dość powierzchowne i ogólnikowe. Ponadto teksty literackie sprzyjające poprzez swoją specyfikę, bardziej niż inne teksty, budowaniu wrażliwości interkulturowej, zostały zupełnie pominięte niemal we wszystkich analizowanych seriach. Teksty proponowane w podręcznikach, szczególnie lokalnych, to głównie teksty nieautentyczne ${ }^{14}$. Niekiedy tekst autentyczny sensu stricto $^{15}$ stanowi wprawdzie podstawę do powstania nowego, niestety

\footnotetext{
${ }^{13}$ Wyjątek stanowią: KängooKängoo Deutsch, Stufen International, em neu, Aspekte.

14 Istotą problemu autentyczności tekstów obcojęzycznych zajmują się dokładniej Grucza (2000), Pfeiffer (2001: 167-168) oraz Adamczak-Krysztofowicz (2003: 85-90), rozróżniając teksty oryginalne zawarte $w$ oryginalnych źródłach obcojęzycznych oraz teksty autentyczne sensu stricto i sensu largo, które mogą dodatkowo zostać specjalnie zdydaktyzowane, aby uwzględnić ważne potrzeby uczących się w procesie glottodydaktycznym.

${ }^{15}$ W odróżnieniu od tekstów autentycznych sensu stricto, stworzonych bez konkretnego celu zastosowania ich na lekcji języka obcego, najczęściej przez i dla rodzimych użytkowników języka dla celów komunikacji poza klasą, teksty autentyczne sensu largo są z jednej strony dostosowane do potrzeb ucznia języka obcego, z drugiej jednak
} 
sztucznego tekstu, gdyż autorzy podręczników, dopasowując tekst do poziomu językowego odbiorców, stosują najczęściej symplifikację lingwistyczną, zamiast naturalnych strategii modyfikacji tekstów autentycznych. ${ }^{16}$ Zadania wspierające rozwój kompetencji interkulturowej zintegrowanej ze sprawnościami językowymi, stanowią w znacznej większości poddanych analizie kursów znikomą ilość. Z kolei zadania, w których rozwój wspomnianej kompetencji jest celem samym w sobie, należą w ogóle do rzadkości. Dodać należy, że niekiedy w podręcznikach pojawiają się zadania, które pozornie wydają się sprzyjać rozwojowi kompetencji interkulturowej lub jednego z jej komponentów. Niestety zdarza się, że niepoprawnie sformułowane polecenia nie tylko nie wspierają jej (ich) kształtowania, lecz wręcz przeciwnie prowadzą do utrwalenia dotychczasowych (wymagających jednak korekty) zachowań, np. niewłaściwe obchodzenie się ze stereotypami narodowymi. Nasuwa się zatem jeden wniosek końcowy - realizacja założeń kształcenia interkulturowego w oparciu o znaczną większość przeanalizowanych materiałów do nauki języka niemieckiego będzie utrudniona i w pełni uzależniona od osoby nauczyciela, tj. od tego, czy widzi on potrzebę, czy chce oraz czy potrafi podczas swoich lekcji wyjść poza ramy narzucone przez podręcznik i poszerzyć oferowane w nim treści lub zmodyfikować je w taki sposób, aby sprzyjały rozwijaniu kompetencji interkulturowej jako całości lub jej poszczególnych komponentów.

\section{Perspektywy i dezyderaty badawcze kształcenia interkulturowego $w$ warunkach zinstytucjonalizowanych}

Wnioski z analiz dokumentów wyznaczających ramy kształcenia językowego w Polsce, wybranych programów nauczania i materiałów do nauki języka niemieckiego skłaniają do pewnych refleksji, których uwzględnienie skutkowałoby udoskonaleniem tychże dokumentów i materiałów, a w efekcie podniesieniem jakości kształcenia językowego w polskich szkołach w zakresie interkulturowości. Pomimo świadomości, że poniższe propozycje zmian sprowadzają się do powinności, które mogą, a nie muszą zostać uwzględnione w kolejnych opracowaniach, jesteśmy zdania, że konieczne jest ich wymienienie oraz skomentowanie.

Dokumenty określające kształt polskiej polityki językowej (ESOKJ, PP) powinny w jednoznaczny sposób odnosić się do celów interkulturowych. Z jednej

strony posiadają istotne z punktu widzenia komunikacji strukturalne cechy naturalnego dyskursu, tzn. wyrażają sensowną intencję autora skierowaną do realnego adresata w konkretnym komunikacyjnym celu i na określony temat.

${ }^{16}$ Naturalne strategie dopasowania komunikatu do możliwości odbiorcy opisano szczegółowo w: Edelhoff (1985: 24-26), Königs (1991: 84), Dakowska (2008: 137-139), Mihułka (2014b: 109-111). 
strony kompetencja interkulturowa jest w nich nazywana i ukazywana jako istotna w kształceniu językowym, z drugiej zaś dokumenty te oprócz sloganowych haseł nie oferują żadnych praktycznych rozwiązań dla osób mających wpływ na jej rozwój u uczniów, tj. dla autorów podręczników czy też nauczycieli. Brak praktycznych wskazówek dotyczących jej rozwijania i ewaluacji oraz brak jej rzeczywistej integracji z innymi celami kształcenia powoduje, że wspieranie rozwoju kompetencji interkulturowej na lekcjach języka obcego postrzegane jest jako pewien „dodatek”, coś dla „chętnych”, a nie obligatoryjny cel lekcji.

W programach nauczania języka niemieckiego zauważyć daje się podobna tendencja, tzn. płaszczyzna celów i płaszczyzna treści wydają się nie mieć ze sobą żadnych punktów stycznych. Autorzy programów powinni mieć jednak świadomość tego, że wyszczególnione i opisane przez nich treści programowe muszą sprzyjać osiąganiu postawionych celów szczegółowych, w tym interkulturowych.

Układ podręczników powinien ponadto umożliwiać zintegrowany rozwój kompetencji interkulturowej i sprawności językowych. Treści dotyczące krajów niemieckiego obszaru językowego, nie mogą ograniczać się do informacji „typowych” jak to ma miejsce obecnie, lecz powinny zawierać treści nieszablonowe, zróżnicowane, motywujące uczniów do nauki tego języka. Ponadto niemiecki obszar językowy nie może zostać ograniczony tylko do Niemiec - podręczniki powinny zawierać więcej informacji o Austrii, Szwajcarii i Lichtensteinie. Liczba zadań, w których rozwój kompetencji interkulturowej jest celem samym w sobie lub jednym z celów, powinna zostać zwiększona, tak aby zadania te występowały w każdej jednostce lekcyjnej, a nie incydentalnie. Formułowanie poleceń do zadań powinno zaś zostać poprzedzone wnikliwą analizą celu, jaki uczniowie osiągną, wykonując dane zadanie. Wówczas uniknie się niefortunnych sformułowań, które niejednokrotnie zupełnie wypaczają przebieg zadania i stawiają pod znakiem zapytania w ogóle jego sens. Podręczniki powinny zawierać więcej tekstów autentycznych sensu largo i sensu stricto, umożliwiających rzeczywiste odkrywanie kultury danego kraju. Last but not least, teksty literackie, jako źródło wiedzy i refleksji kulturoznawczej nie tyle w sensie uświadomienia sobie i zrozumienia realiów, co w sensie zagłębienia się w świat ludzi, powinny stać się nieodłącznym elementem każdego rozdziału w podręczniku.

Niniejszy artykuł jest przyczynkiem do dyskusji na temat kształcenia interkulturowego w dydaktyce języka niemieckiego w Polsce i w badaniach germanistów. Jednak ocena stopnia realizacji założeń kształcenia interkulturowego na lekcji języka niemieckiego jako obcego w Polsce nie może ograniczać się tylko do analiz dokumentów określających ramy kształcenia językowego w naszym kraju i (wybranych) materiałów do nauki języka niemieckiego dla poziomu początkującego i zaawansowanego. Naszym zdaniem warto skupić się w kolejnych pracach przeglądowych na pozostałych elementach układu glottodydaktycznego Pfeiffera 
(2001: 21). Przedstawiając przykładowo jego centralny trzon, tj. ucznia i nauczyciela, należy zwrócić szczególną uwagę na poziom rozwoju ich kompetencji interkulturowej, a co za tym idzie na umiejętność mediacji między co najmniej dwiema kulturami. Ponadto warto analizując kształcenie interkulturowe w dydaktyce języka niemieckiego w Polsce i w badaniach germanistów również zbilansować wszystkie procedury, w tym szczególnie metody i techniki glottodydaktyczne, które zostały wypracowane w celu stopniowego i efektywnego rozwijania kompetencji interkulturowej w edukacji szkolnej i językowej.

\section{BIBLIOGRAFIA}

Adamczak-Krysztofowicz S. (2003), Texte als Grundlage der Kommunikation zwischen Kulturen. Eine Studie zur Landes- und Kulturkundevermittlung im DaF-Studium in Polen. Hamburg: Dr. Kovač.

Adamczak-Krysztofowicz S. (2007), Znaczenie podejścia interkulturowego w akademickiej dydaktyce języka niemieckiego. Rys historyczny i krótkie podsumowanie najważniejszych wniosków z badań własnych (w) „Przegląd Glottodydaktyczny", nr 22, str. 39-46.

Adamczak-Krysztofowicz S., Kowalonek-Janczarek M., Maciejewski M., Sopata A. (2011), Vorwort (w) Adamczak-Krysztofowicz S., Kowalonek-Janczarek M., Maciejewski M., Sopata A. (red.), Aktuelle Probleme der angewandten Linguistik. Interkulturalität als Schlüsselkompetenz für Fremdsprachenlehrer, Übersetzer und Mediatoren. Poznań: Wydawnictwo Naukowe UAM, str. 7-11.

Adamczak-Krysztofowicz S., Jentges S., Stork A. (2015), Fremde und eigene Gewässer - Einführende Gedanken und Aktivitäten zum interkulturellen Lernen im Fremdsprachenunterricht (w) Cerri Ch., Jentges S. (red.), Raumwahrnehmung, interkulturelles Lernen und Fremdsprachenunterricht. Baltmannsweiler: Schneider Verlag Hohengehren, str. 11-32.

Aleksandrowicz-Pędich L. (2005), Międzykulturowość na lekcjach języków obcych. Białystok: Wydawnictwo UwB.

Altmayer C. (2004), Kultur als Hypertext. Zur Theorie und Praxis der Kulturwissenschaft im Fach Deutsch als Fremdsprache. München: iudicium.

Auernheimer G. (2010), Interkulturelle Kommunikation, mehrdimensional betrachtet, mit Konsequenzen für das Verständnis von multikultureller Kompetenz (w) Auernheimer G. (red.), Interkulturelle Kompetenz und pädagogische Professionalität. 3. Aufl. Wiesbaden: Verlag für Sozialwissenschaften, str. 35-65.

Bandura E. (2007), Nauczyciel jako mediator kulturowy. Kraków: Krakowskie Towarzystwo „Tertium”. 
Białek M. (2009), Kształcenie międzykulturowe w edukacji językowej. Wrocław: Oficyna Wydawnicza ATUT - Wrocławskie Wydawnictwo Oświatowe.

Błażek A., (2008), Evaluation interkultureller Kompetenz bei angehenden Deutschlehrerinnen und -lehrern in Polen. Poznań: Wydawnictwo Naukowe UAM.

Bolten J. (2007), Interkulturelle Kompetenz. Thüringen: Landeszentrale für Politische Bildung.

Byram M. (1997), Teaching and Assessing Intercultural Communicative Competence. Clevedon: Multilingual Matters.

Chojnacka-Gärtner J. (2016), Bereitet die Oberschule auf das Philologiestudium vor? Die interkulturellen Erfahrungen der Studienanfänger am Beispiel der Germanistikstudenten der PWSZ in Konin (w) Mihułka K. Bąk P., Chojnacka-Gärtner J. (red.), Interkulturalität in Theorie und Praxis der Glottodidaktik und Translatorik. Rzeszów: Wydawnictwo Uniwersytetu Rzeszowskiego, str. 59-71.

Dakowska M. (2008), Psycholingwistyczne podstawy dydaktyki języków obcych. Warszawa: Wydawnictwo Naukowe PWN.

Edelhoff Ch. (1985), Authentizität im Fremdsprachenunterricht (w) Edelhoff Ch. (red.), Authentische Texte im Deutschunterricht. Einführung und Unterrichtsmodelle. München: Max Hueber, str. 7-30.

Europejski system kształcenia językowego: uczenie się, nauczanie, ocenianie. (2003), Warszawa: Wydawnictwo CODN.

Fus A. (2015), Fremdverstehen und interkulturelle Kompetenz in der Didaktik des Deutschen als Fremdsprache. Niepublikowana praca doktorska.

Grucza F. (1992a), Wstęp (w) Grucza F. (red.), Język, kultura-kompetencja kulturowa. Materiały z XIII Sympozjum zorganizowanego przez Instytut Lingwistyki Stosowanej UW Zaborów, 5-8 listopada 1987 r. Warszawa: Wydawnictwa Uniwersytetu Warszawskiego, str. 5-8.

Grucza F. (1992b), Kulturowe determinanty języka oraz komunikacji językowej (w) Grucza F. (red.), Język, kultura - kompetencja kulturowa. Materiały z XIII Sympozjum zorganizowanego przez Instytut Lingwistyki Stosowanej UW Zaborów, 5-8 listopada 1987 r. Warszawa: Wydawnictwa Uniwersytetu Warszawskiego, str. 9-70.

Grucza S. (2000), Kommunikative Adäquatheit glottodidaktischer Texte -Zur Kritik des sog. Authentizitätspostulats (w) „Deutsch in Dialog“, nr 2, str. 73-103.

Hansen K. P. (2011), Kultur und Kulturwissenschaft. Eine Einführung. 4. Aufl. Tübingen u.a.: Francke (UTB).

Jańska M.U. (2006), Interkulturelles Lernen in der bilingualen deutsch-polnischen Erziehung. Evaluation der Unterrichtsmaterialien für den frühen fremdsprachlichen Deutschunterricht in Polen. Wrocław-Dresden: Neisse Verlag. Jaroszewska A. (2006), Problematyka wielo-i międzykulturowości w wybranych programach wczesnoszkolnego nauczania języków obcych (w) Krieger-Knieja J., 
Paprocka-Piotrowska U. (red.), Komunikacja językowa w społeczeństwie informacyjnym. Lublin: Towarzystwo Naukowe KUL, str. 296-308.

Jaroszewska A. (2007), Nauczanie języka obcego w kształceniu wczesnoszkolnym. Rozwój świadomości wielokulturowej dziecka. Wrocław: Oficyna Wydawnicza ATUT. Wrocławskie Wydawnictwo Oświatowe.

Jarząbek A.D. (2016), Zadania służq̨ce afektywnym celom kształcenia międzykulturowego w podręcznikach do nauczania języka niemieckiego w gimnazjum (w) Jaroszewska A. i in. (red.), Wielojęzyczność i międzykulturowość na lekcji języka obcego. Między teorią a praktyką nauczania. Warszawa: Instytut Germanistyki UW, Instytut Romanistyki UW, str. 189-202.

Jarząbek A.D. (2017), Zadania rozwijajqce kompetencję międzykulturowq w podręcznikach do nauczania języka niemieckiego w gimnazjum (w) „Prace Językoznawcze”, nr XIX/1, str. 51-70.

Karolak Cz. (1999), Dydaktyka literatury wobec potrzeb nauki języka w warunkach obcokulturowych. Wydawnictwo Naukowe UAM: Poznań.

Karpińska-Musiał, B. (2015), Międzykulturowość w glottodydaktyce. O zwiqzku świadomości metajęzykoznawczej z kompetencjq międzykulturowq $w$ akademickim kształceniu nauczycieli języków obcych. Gdańsk: Wydawnictwo Uniwersytetu Gdańskiego.

Königs F.G. (1991), 'Ein Text über Texte': Zur Mehrdimensionalität von Texten im und für den Fremdsprachenunterricht (w) Bausch H., Christ K.R., Krumm H.J. (red.), Texte im Fremdsprachenunterricht als Forschungsgegenstand. Arbeitspapiere der 11. Frühjahrskonferenz zur Erforschung des Fremdsprachenunterrichts. Bochum: Universitätsverlag Dr. N. Brockmeyer, str. 79-89. Mackiewicz M. (2008), Podręcznik do nauki języka niemieckiego jako źródło międzykulturowej refleksji: czy istnieje model idealny? Analiza trzech przypadków (w) Jodłowiec M., Niżegorodcew A. (red.), W stronę nowoczesnego nauczania języków obcych. Kraków: Krakowskie Towarzystwo „Tertium”. (= „Język a komunikacja” nr 22), str. 203-213.

Mackiewicz M. (2010), Standardy kulturowe a dydaktyka języków obcych (w) Mackiewicz M. (red.), Kompetencja interkulturowa w teorii i praktyce edukacyjnej. Poznań: Wydawnictwo Wyższej Szkoły Bankowej, str. 137-149.

Maletzke G. (1996), Interkulturelle Kommunikation. Zur Interaktion zwischen Menschen verschiedener Kulturen. Opladen: Westdeutscher Verlag.

Mihułka K. (2010), Stereotype und Vorurteile in der deutsch-polnischen Wahrnehmung. Eine empirische Studie zur Evaluation des Landesbildes durch Germanistikstudenten. Rzeszów: Wydawnictwo Uniwersytetu Rzeszowskiego.

Mihułka K. (2012), Rozwój kompetencji interkulturowej w warunkach szkolnych. Mity a polska rzeczywistość. Rzeszów: Wydawnictwo Uniwersytetu Rzeszowskiego. 
Mihułka K. (2014a), Wpływ materiałów do nauki języka obcego na proces kształtowania kompetencji interkulturowej - spostrzeżenia i wnioski z analizy kursów "Alles klar - zakres odstawowy” $i$ „Direkt” (w) SujeckaZając J. i in. (red.), Inspiracja, motywacja, sukces. Rola materiałów dydaktycznych i form pracy na lekcji języka obcego. Warszawa: Instytut Germanistyki i Romanistyki UW, str. 185-196.

Mihułka K., (2014b), Wer Fremdsprachenerwerb sagt, muss auch Text sagen. Anmerkungen zur Problematik der "authentischen Texte" im und für den Fremdsprachenunterricht. (w) Bąk P., Rolek B., Sieradzka M. (red.), Text-Satz - Wort. Rzeszów: Wydawnictwo Uniwersytetu Rzeszowskiego, str. 100-117. Mihułka K., Bąk P., Chojnacka-Gärtner J. (2016), Vorwort (w) Mihułka K., Bąk P., Chojnacka-Gärtner, J. (red.), Interkulturalität in Theorie und Praxis der Glottodidaktik und Translatorik. Rzeszów: Wydawnictwo Uniwersytetu Rzeszowskiego, str. 7-8.

Myczko K. (2005), Kompetencja interkulturowa jako cel kształcenia językowego (w) Mackiewicz M. (red.), Dydaktyka języków obcych a kompetencja kulturowa i komunikacja interkulturowa. Poznań: Wydawnictwo Wyższej Szkoły Bankowej, str. 27-35.

Pfeiffer W. (2001), Nauka języków obcych. Od praktyki do praktyki. Poznań: Wagros. Pfeiffer W. (2004), Interkulturowa glottopedagogika - nowa dyskusja naukowa? Uwagi do dyskusji (w) Badstübner-Kizik C., Rozalowska-Żądło R., Uniszewska A. (red.), Nauczanie i uczenie się języków obcych. Prace ofiarowane Profesor Halinie Stasiak w 70. rocznicę urodzin. Gdańsk: Wydawnictwo Uniwersytetu Gdańskiego, str. 71-84.

Podstawa programowa kształcenia ogólnego z komentarzem. Szkoła podstawowa. Język obcy nowożytny. (2017). Warszawa: MEN / ORE.

Rada Europy (2001/2003), Europejski system kształcenia językowego: uczenie się, nauczanie, ocenianie. Warszawa: Wydawnictwo CODN.

Torenc M. (2007), Nauczanie międzykulturowe - implikacje glottodydaktyczne. Wroclaw: Oficyna Wydawnicza ATUT - Wrocławskie Wydawnictwo Oświatowe.

Zawadzka E. (2000), Glottodydaktyczne aspekty interkulturowości (w) Krzeszowski T., Lukszyn J., Namowicz T. (red.), Problemy komunikacji międzykulturowej: lingwistyka, translatoryka, glottodydaktyka. Warszawa: Graf Punkt, str. 451-465.

Zawadzka E. (2004), Nauczyciele języków obcych w dobie przemian. Kraków: Impuls.

\section{Netografia}

https://cke.gov.pl/images/_EGZAMIN_OSMOKLASISTY/Podstawa_programo wa/SP_PP_2017_Jezyk_obcy_nowozytny.pdf [DW 10.02.2019] 